\title{
Cross-country-heterogeneous and Time-varying Effects of Unconventional Monetary Policies in AEs on Portfolio Inflows to EMEs
}

\author{
Kyoungsoo Yoon* \\ Christophe Hurlin**
}

The views expressed herein are those of the authors and do not necessarily reflect the official views of the Bank of Korea. When reporting or citing this paper, the author's name should always be stated explicitly.

\footnotetext{
* Bank of Korea, E-mail: kyoungsoo.yoon@bok.or.kr.

** University of Orléan, E-mail: christophe.hurlin@univ-orleans.fr.
}

Financial support from the Bank of Korea is gratefully acknowledged. This paper was presented at the $2^{\text {nd }}$ International Finance Forum hosted by the Bank of Korea and a BOK brown-bag seminar. The authors would like to thank Sangdae Ryoo, Keuncheol Ha, Seungheon Lee, Chanho Park, Soyoung Kim, Dae Jung Yang, Geun-young Kim and participants at the forum and the seminar for their helpful comments. Our special thanks go to Sion An for his excellent research assistance. 


\section{Contents}

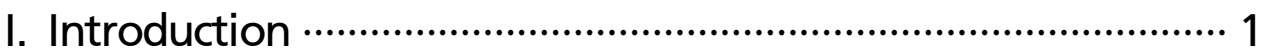

II. Methodology ……....................................................... 5

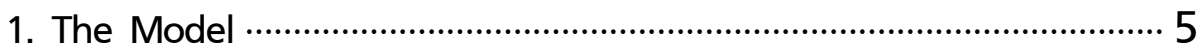

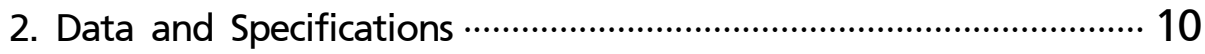

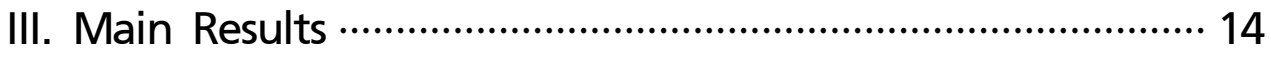

1. Effects of Global Liquidity Growth on Portfolio Inflows to EMEs ……………………………………... 14

2. Effects of Growth in Fed's Security Assets on Portfolio Inflows to EMEs ……………………………………… 20

3. Effects of US 10-year T-bond Yield on

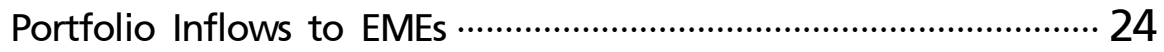

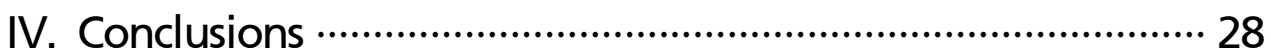

References …….................................................................. 30

Appendix 


\section{Cross-country-heterogeneous and Time-varying Effects of Unconventional Monetary Policies in AEs on Portfolio Inflows to EMEs}

This paper examines cross-country heterogeneity and time-variability in the effects of unconventional monetary policies (UMPs) in advanced economies (AEs) on portfolio inflows to emerging economies (EMEs), with a panel smooth transition regression model. The drivers of the two dimensional nonlinearities are country-specific factors such as the current account, real effective exchange rate deviation from its historical average, and foreign exchange reserves. The elasticity of portfolio inflows to EMEs with respect to a direct quantitative measure of UMP, growth in the Fed's security assets, tends to be higher with a higher current account, higher exchange rate appreciation expectations, and greater foreign exchange reserve holdings, while the results are the opposite with a price measure of UMP, a change in the US 10-year Treasury yield. These results imply that a price UMP shock from news about or impending $\mathrm{QE}$ tapering would more adversely affect an EME with a weaker external sector. If $\mathrm{QE}$ tapering is actually implemented with clearer signs of economic recovery in AEs, the increase in global liquidity due to $\mathrm{AE}$ recoveries will help EMEs muddle relatively easily through the quantitative shock from the reduction in the Fed's security assets.

Keywords: portfolio inflows, unconventional monetary policy, emerging market economies, cross-country heterogeneity, time variability, nonlinearity, panel smooth transition regression model

JEL Classification: E5, F21, F3, F42, G15, C23 


\section{Introduction}

Since the Global Financial Crisis (GFC) in 2008, major reserve currency economies such as the US, the Euro area, Japan and the UK have introduced or reinforced dramatic easing of their monetary policies to cope with severe recessions. In the face of lower bound policy rates, they have chosen to supply liquidity by large-scale asset purchases (LSAPs) in the market, so-called unconventional monetary policies (UMPs) or quantitative easing (QE). Until very recently, these policies have been blamed for the increasing international portfolio investment flows to emerging market economies (EMEs) and subsequently increasing appreciation pressures or overheating in EMEs. However, when Ben S. Bernanke, Chairman of the Federal Reserve System, gave hints about near future tapering of $\mathrm{QE}$ in around mid-June 2013, some EMEs had opposite concerns - about being innocent bystander victims of abrupt outflows of international portfolio investment from their markets. Recent signs of this in fact happening seem to justify EMEs' prior concerns about volatile portfolio inflows fueled by advanced economies (AEs)' $\mathrm{QE}$, and also their preemptive policy responses adopted such as macro-prudential measures.

Though the effects of AEs' UMPs on portfolio inflows to EMEs are generally common phenomena for most emerging markets, according to the existing literature, actual portfolio inflows to EMEs differ very much, both among countries and between periods, as shown in Figure 1. Without considering this cross-country heterogeneity and nonlinearity across the time dimension, we may not get a right picture of the effects of the UMPs on international portfolio investment in EMEs. ${ }^{1)}$

1) We are also able to find evidence that there exist effects of UMPs in AEs on portfolio inflows to EMEs using a linear panel regression model in Table A.2 in the Appendix. The model specifications in the table are same as those in this paper's nonlinear PSTR model. However, they do not consider the two dimensional heterogeneity. We can only find the possibility of time dimensional nonlinearity with the results in the table. This is because the estimates differ in their magnitudes and statistical significances depending upon the period. 


\section{Figure 1: Portfolio Inflows to $15 \mathrm{EMEs}^{1)}$}
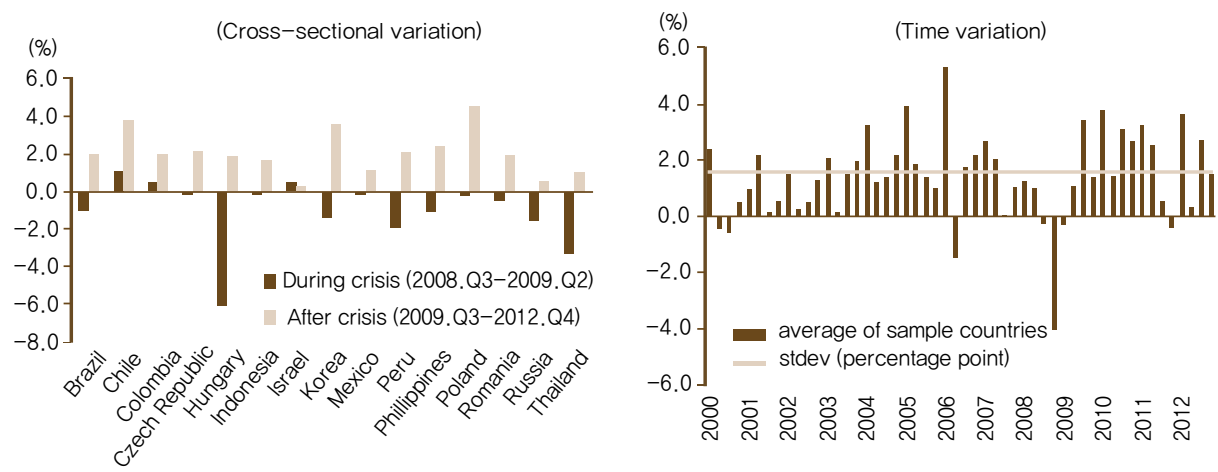

Note: 1) Portfolio inflows scaled by each economy's GDP

Sources: IMF IFS, and authors' calculations

In this regard, this paper tries to answer several questions that naturally arise in EMEs: (1) Are there heterogeneity across countries and time dimensional nonlinearity in the magnitudes of the effects of AEs' UMPs on portfolio inflows to EMEs? (2) If so, what drives such heterogeneity and time instability? (3) Since the GFC the increases in capital inflows to EMEs have mainly taken the form of portfolio investment. Consequently, the ultimate unwinding process of AE UMPs will cause shocks to small open EMEs mainly through this type of investment in the future. In this respect, another question to be addressed is: How will the exit policies in AEs affect international portfolio investment in EMEs?

To answer these questions, this paper uses a Panel Smooth Transition/ Threshold Regression (PSTR) model with threshold variables varying across economies and also over time. To be more specific, we can analyze how the UMPs undertaken in AEs affect EMEs differently through their country specific threshold variables. This novel application of the PSTR model to the relationship between UMPs and portfolio inflows to EMEs allows us to capture cross-country heterogeneity and nonlinearity across the time dimension that can be interpreted as a time-heterogeneity. The three threshold variables chosen from among possible candidates in the literature are the current account balance relative to GDP, deviation of the real effective exchange rate (REER) from its historical average (REER gap), and foreign exchange $(\mathrm{FX})$ reserves relative to GDP. The various threshold variables in the 
model turn out to be the drivers of heterogeneity across two dimensions (cross-country and time). We measure the UMPs with three variables: the growth in global liquidity, growth in the Fed's security assets, and the change in the US 10-year Treasury bond rate. Global liquidity is defined as G3 currency (US dollars, Euro, Japanese Yen) - denominated credits in the world as a whole. In order to affect capital inflows to EMEs, the 'public liquidity' defined as the sum of the G3's high-powered money needs to be converted into credit created in the private sector. Global liquidity is thus an indirect measure of UMPs, because it is subject to private sector credit demand and supply.2)

With nine specifications of the PSTR model from combinations between the three UMP variables and the three threshold variables we have three main findings related to our research questions. First, there are cross-country heterogeneity and time-variability in the effects of the AE UMPs on portfolio inflows to EMEs. The two dimensional heterogeneities are driven by the three country-specific threshold variables mentioned above.

Second, the elasticity of portfolio inflows to an EME with respect to the Fed's security asset growth, a direct quantitative measure of UMP, tends to be higher with a higher current account, with a lower REER gap, and with a larger amount of FX reserves, while the results reverse with a direct price measure of UMP, the US 10 -year T-bond rate. However, an economy with a severe current account deficit has a higher elasticity with respect to global liquidity, the indirect quantitative measure of UMP. This seems to be due to both possible differentiation among EMEs with the passage of time after a negative quantitative UMP shock, and to the economy's own funding needs from the balance of payments relationship.

Third, the first two results imply that a change in US long-term interest rates, "a price UMP shock" from news about or impending QE tapering, will affect an EME with relatively weak external sector indicators more adversely. If $\mathrm{QE}$ tapering is

2) Global liquidity defined in this paper is the sum of i ) domestic credit to nonfinancial sectors in the G3 (US, Euro area and Japan) from the national flows of funds, excluding identified credit in non-domestic currencies, and ii ) G3 currency-denominated cross-border financial claims on nonbanks in the world from the BIS locational banking statistics. It is one of the indicators suggested by the CGFS (Committee on the Global Financial System) under the BIS to capture global liquidity conditions. Yoon and Kim (2012) analyze the effects of global liquidity defined in the same way on capital inflows to EMEs. Refer to the CGFS $(2011,2012)$ for more details on global liquidity indicators. 
actually implemented, based upon good signs of economic recoveries in AEs, an EME with more depreciated real exchange rates and higher FX reserves will experience a more mitigated negative effect from the "quantitative UMP shock" in the form of a reduction in the Fed's security assets because of the offsetting effect from an increase in global liquidity due to the ultimately increased private sector credit creation. This prediction presumes that the implementation of AEs' QE tapering is done by and large in line with market expectations.

There is quite a lot of literature on the effects of the UMPs on capital flows to EMEs. A common finding in the recent related literature is that the UMPs in AEs do indeed affect capital flows to EMEs, despite the differences in the magnitudes of the effects and in the types of capital flows. However, most studies do not consider country-specific factors in the context of UMPs to explain the high heterogeneity of capital inflows to EMEs. In other words, they do not deal with country-specific factors as channels through which UMPs are propagating to EMEs in the form of portfolio inflows.

Fratzscher (2012), for example, finds with a factor model that the capital flows during the GFC are able to be explained mainly by common factors (push factors) such as crisis events, global liquidity and risk, while the subsequent surges in capital flows in 2009-10 and their heterogeneity across economies are due mainly to country-specific determinants (pull factors) such as domestic institutions and macroeconomic fundamentals. Pull factors play their role in the heterogeneity of capital flows among economies, but they do not play an explicit role in the effect of push factors on capital flows. Fratzscher et al. (2013) show, with a linear panel model, that the Fed's QE affects both capital inflows to EMEs and asset prices in the markets, with the effects on the latter being comparatively larger. They also try to measure cross-country heterogeneity by comparing coefficient estimates with the same linear regression model applied to each EME. Moore et al. (2013) argue that a 10-basis point reduction in the 10-year US Treasury yield increases the share of foreign ownership of emerging market debt by $0.4 \%$ p, which reduces government bond yields in EMEs by about 1.7 basis points. However, their panel model does not explain any possible differences in sensitivity among EMEs. Ahmed and Zlate (2013) argue that the effects of the US UMPs on total net capital inflows to EMEs 
are not statistically significant, and that the US UMPs are only ones among several important factors. They do consider any time instability by separating pre- and post-crisis samples, but do not consider any possible heterogeneity across EMEs.

As far as methodology, Gauvin et al. (2013) use a PSTR model like that in this paper to study portfolio flows to EMEs. They find time-dimensional nonlinearity of the effects of US and EU policy uncertainty on bond and equity inflows to EMEs with time as a threshold variable. In contrast to this paper, however, they do not consider cross-country heterogeneity in these effects.

The rest of this paper consists of three sections. Section II describes the data and specifications as well as our model. Section III presents the results of estimation. In the last section, IV, we then briefly conclude with some policy implications derived from the main findings.

\section{Methodology}

\section{The Model}

\subsection{Panel Smooth Transition/Threshold Regression Model}

We consider a Panel Smooth Threshold Regression Model (Gonzalez, Teräsvirta and Van Dijk, 2005), defined as follows:

$$
\begin{aligned}
& y_{i t}=\alpha_{i}+\gamma_{0} x_{i t}+\beta_{0} z_{i t} \\
& +\left(\gamma_{1} x_{i t}+\beta_{1} z_{i t}\right) \times g\left(q_{i t-1} ; \gamma, c\right)+\varepsilon_{i t},
\end{aligned}
$$

where $y_{i t}$ denotes the portfolio inflows to a given $\operatorname{EME} i \in\{1, \cdots N\}$ at time $t, x_{i t}$ a set of control variables and $z_{i t}$ a UMP variable. The transition function $g\left(q_{i t-1}: \gamma, c\right)$ is a continuous and bounded function of a threshold variable $q_{i t-1}$. Here, we consider a logistic transition function defined as follows: 


$$
g\left(q_{i t}: \gamma, c\right)=1 /\left\{1+\exp \left[-\gamma\left(q_{i t}-c\right)\right]\right\}
$$

where $c$ denotes a location parameter and where the parameter $\gamma>0$ determines the slope of the transition function. ${ }^{3)}$ This model can be rewritten in vectorial form as:

$$
y_{i t}=\alpha_{i}+W_{i t} \Psi_{0}+W_{i t} \Psi_{1} g\left(q_{i t-1} ; \gamma, c\right)+\varepsilon_{i t},
$$

with $\Psi_{j}=\left(\gamma_{j} \beta_{j}\right)^{T}$ for $j=\{0,1\}$ and $W_{i t}=\left(x_{i t} z_{i t}\right)$.

For our purposes, this PSTR specification has a great advantage in that it allows the parameters to vary across countries (heterogeneity issue), but also with time (stability issue). More precisely, it provides a parametric approach to the cross-country heterogeneity and to the time instability of the slope parameters, since these parameters change smoothly as functions of the threshold variable. For instance, the elasticity of the capital flows $y_{i t}$ with respect to the UMP variable $z_{i t}$ can be defined as the weighted average of the structural parameters $\beta_{0}$ and $\beta_{1}$ defined by:4)

$$
e_{i t}^{(z)}=\frac{\partial y_{i t}}{\partial z_{i t}}=\beta_{0}+\beta_{1} g\left(q_{i t-1} ; \gamma, c\right) .
$$

Since the threshold function $\mathrm{g}($.$) is defined over [0,1]$, this expression means that the elasticity ranges between $\beta_{0}$ and $\beta_{0}+\beta_{1}$, given the values of the threshold variable $q_{i t-1}$. Hence, the PSTR can be viewed as a model with an infinite number

3) A more general specification of the transition function is the following:

$$
g\left(q_{i t}: \gamma, c\right)=\left[1+\exp \left(-\gamma \prod_{z=1}^{m}\left(q_{i t}-c_{z}\right)\right)\right]^{-1}, \gamma>0, c_{1} \leq \cdots \leq c_{m}
$$

where $c=\left(c_{1}, \cdots, c_{m}\right)$ denotes an $m$-dimensional vector of the location parameters and $\gamma$ determines the slope of the transition function. The transition function with $m>1$ allows different types of changes in the elasticities and a very flexible parametrization. For instance, if $m=2, c_{1}=c_{2}=c$ and $\gamma$ tends to infinity, the transition function defines a three-regime model whose outer regimes are identical and different from the mid regime. More generally, the value of $m$ affects the regime-switching behaviour. In a model with one transition function, the choice $m=1$ implies a monotonic change of the coefficient of $z_{i t}$ from $\beta_{0}$ to $\beta_{0}+\beta_{1}$ as $q_{i t}$ increases. If $m=2$ (and assuming $c_{1}=c_{2}=c$ ), it implies a symmetric change in the elasticity around $q_{i t}=c$.

4) The same conclusions are valid for the elasticities associated with $x_{i t}$. 
of regimes: each regime is characterized by specific values for the slope parameters, depending upon the value of the threshold variable. Note that it is generally difficult to directly interpret the parameters $\Psi_{0}$ and $\Psi_{1}$ in equation (4), since they only correspond to extreme situations where the function $\mathrm{g}($.$) tends to one (or$ $q_{i t-1} \rightarrow \infty$ ) or to zero (or $q_{i t-1} \rightarrow-\infty$ ). It is generally preferable to interpret (i), the sign of the parameter $\Psi_{1}$ which Indicates an increase or a decrease in elasticity with the value of the threshold variable, and (ii) the time varying and individual elasticity of the portflolio inflows $y_{i t}$ with respect to the UMP variable (or other control variables) given by equation (5).

Finally, this model can be considered as a generalization of the Panel Threshold Regression (PTR) model proposed by Hansen (1999) and the panel linear model with individual effects. In Figure 2 the transition function $\mathrm{g}($.$) is displayed for$ various values of the parameter $\gamma$. When the parameter $\gamma$ tends to infinity, the transition function tends toward the indicator function, i.e. $g\left(q_{i t-1} ; \gamma, c\right)=I_{\left(q_{i t-1} \geq c\right)}$. Thus, when $\gamma$ tends to infinity the PSTR corresponds to the PTR model with:

$$
\begin{gathered}
y_{i t}=\alpha_{i}+W_{i t} \Psi_{0}+W_{i t} \Psi_{1} I_{\left(q_{i t-1} \geq c\right)}+\varepsilon_{i t} \\
I_{\left(q_{i t-1} \geq c\right)}=\left\{\begin{array}{ll}
1 & \text { if } q_{i t-1} \geq c \\
0 & \text { otherwise }
\end{array} .\right.
\end{gathered}
$$

Figure 2: Transition Function $g_{j}\left(q_{i t} ; \gamma_{j}, c_{j}\right)$ for $c=0$

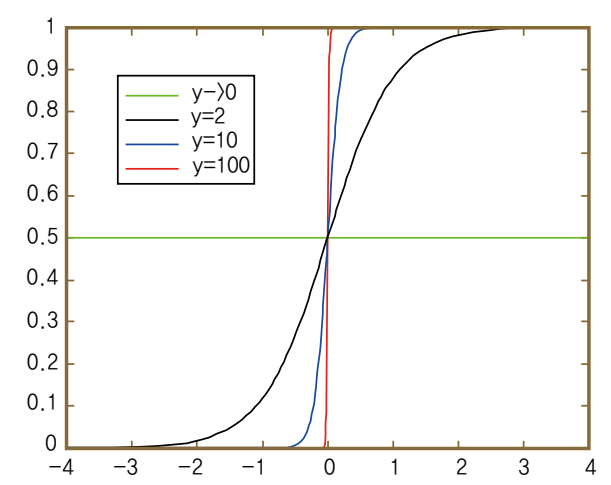


In this case, the elasticity of the UMP variable $z_{i t}$ switches between two extreme values given the level of the threshold variable: $e_{i t}^{(z)}=\beta_{0}$ if $q_{i t-1}<c$ and $e_{i t}^{(z)}=\beta_{0}+\beta_{1}$ if $q_{i t-1} \leq c$. In contrast, when the slope parameter $\gamma$ tends to zero the transition function $\mathrm{g}($.$) is constant and the model corresponds to the standard$ linear model with individual effects (the so-called "within" model), i.e. with constant and homogenous coefficients:

$$
y_{i t}=\alpha_{i} W_{i t} \Gamma+\varepsilon_{i t},
$$

with $\Gamma=\Psi_{0}+\Psi_{1} / 2$.

The PSTR model can be generalized to $r+1$ extreme regimes as follows:

$$
y=\alpha_{i}+W \Psi_{0}+\sum_{j=1}^{r} W_{i t-1} \Psi_{j} g_{j}\left(q_{i t-1} ; \gamma_{j}, c_{j}\right)+\varepsilon
$$

where the $r$ transition functions $g_{j}\left(q_{i t-1} ; \gamma_{j}, c_{j}\right)$ depend on a specific slope parameter $\gamma_{j}$ and on a location parameter $c_{j}$. In this generalization, the coefficient of the UMP variable $z_{i t}$ for the $i^{t h}$ country at time $t$ is defined by the weighted average of the $r+1$ parameters $\beta_{j}$ associated with the $r+1$ extreme regimes:

$$
e_{i t}^{(z)}=\frac{\delta y_{i t}}{\delta z_{i t}}=\beta_{0}+\sum_{j=1}^{r} \beta_{j} g_{j}\left(q_{i t-1} ; \gamma_{j}, c_{j}\right)
$$

\subsection{Specification Tests and Estimation}

The estimation of the parameters of the PSTR model consists of eliminating the individual effects $\alpha_{i}$ by removing individual-specific means, and in then applying nonlinear least squares to the transformed model (see Gonzalez, Teräsvirta and Van Dijk, 2005, or Colletaz and Hurlin, 2006, for more details). Gonzalez, Teräsvirta and Van Dijk (2005) propose a testing procedure in order (i) to test the linearity against the PSTR model, and (ii) to determine the number $r$ of transition functions, i.e. the number of extreme regimes which is equal to $r+1$. Testing the 
linearity in a PSTR model can be done by testing $H_{0}: r=0$ or $H_{0}: \Psi_{1}=0$.

The test will be nonstandard in both cases, however, since under $H_{0}$ the PSTR model contains unidentified nuisance parameters, an issue well known in the literature devoted to time series threshold models (Hansen, 1996). A possible solution is to replace the transition function $g_{j}\left(q_{i t-1} ; \gamma_{j}, c_{j}\right)$ by its first-order Taylor expansion around $\gamma=0$ and to test an equivalent hypothesis in an auxiliary regression. We then obtain:

$$
y_{i t}=\alpha_{i}+W_{i t} \Pi_{0}+W_{i t} \Pi_{1} q_{i t-1}+\mu_{i t}
$$

In this first-order Taylor expansion, the parameters $\Pi_{i}$ are proportional to the slope parameter $\gamma$ of the transition function. Thus, testing the null of the linearity of the model against the PSTR simply consists of testing $H_{0}: \Pi_{1}=0$ in this linear panel model. If we denote $S S R_{0}$ as the panel sum of the squared residuals under $H_{0}$ (linear panel model with individual effects) and $S S R_{1}$ as the panel sum of the squared residuals under $H_{1}$ (PSTR model with two regimes), the corresponding F-statistic is then defined by:

$$
L R=\left(S S R_{0}-S S R_{1}\right) /\left(\left[S S R_{0} /(T N-N-1)\right]\right.
$$

Under the null hypothesis, this F-statistic has an approximate $F(1, T N-N-1)$ distribution.

The logic is similar when it comes to testing the number of transition functions in the model, or equivalently the number of extreme regimes. The idea is as follows: we use a sequential approach by testing the null hypothesis of no remaining nonlinearity in the transition function. For instance, let us assume that we have rejected the linearity hypothesis. The issue is then to test whether there is one transition function $\left(H_{0}: r=1\right)$ or at least two transition functions $\left(H_{0}: r=2\right)$. Let us assume that the model with $r=2$ is defined as:

$$
y_{i t}=\alpha_{i}+W_{i t} \Psi_{0}+W_{i t} \Psi_{1} g_{1}\left(q_{i t-1} ; \gamma_{1}, c_{1}\right)+W_{i t} \Psi_{2} g_{2}\left(q_{i t-1} ; \gamma_{2}, c_{2}\right)+v_{i t}
$$


The logic of the test consists in replacing the second transition function by its first-order Taylor expansion around $\gamma_{2}=0$ and then testing the linear constraints on the parameters. If we use the first-order Taylor approximation of $g_{2}\left(q_{i t-1} ; \gamma_{2}, c_{2}\right)$, the model becomes:

$$
y_{i t}=\alpha_{i}+W_{i t} \Psi_{0}+W_{i t} \Psi_{1} g_{1}\left(q_{i t-1} ; \gamma_{1}, c_{1}\right)+W_{i t} \Pi_{2} q_{i t-1}+v_{i t}
$$

and the test of no remaining nonlinearity is simply defined by $H_{0}: \Pi_{2}=0$. Let us denote $S S R_{0}$ as the panel sum of the squared residuals under $H_{0}$, i.e. in a PSTR model with one transition function. Let us denote $S S R_{1}$ as the sum of the squared residuals of the transformed model (equation 14). The F-statistic can be calculated in the same way as in the previous examples by adjusting the number of degrees of freedom. The testing procedure is then as follows: Given a PSTR model with $r=r^{*}$, we test the null $H_{0}: r=r^{*}$ against $H_{1}: r=r^{*}+1$. If $H_{0}$ is not rejected the procedure ends. Otherwise, the null hypothesis $H_{0}: r=r^{*}+1$ is tested against $H_{1}: r=r^{*}+2$, and the testing procedure continues until the first acceptance of $H_{0}$. Given the sequential aspect of this testing procedure, at each step of the procedure the significance level must be reduced by a constant factor $0<\rho<1$ in order to avoid excessively large models. Here, we assume that $\rho=0.5$.

\section{Data and Specifications}

\subsection{Data}

Our analysis is based on a quarterly panel data set including 15 EMEs for the period from 2000.Q1 to 2012.Q4. Some of the data are not available for a few economies during a few quarters, which results in an unbalanced data set. The 15 EMEs cover most of the important emerging economies around the world whose data are available. Specifically, it covers five Latin American economies (Brazil, Chile, Columbia, Mexico and Peru), four Asian ones (Indonesia, Korea, the Philippines and Thailand), and five European countries (the Czech Republic, Hungary, Poland, 
Romania and Russia) as well as Israel. We exclude Argentina and Turkey given their experiences of crisis in the early 2000s, together with financial centers such as Hong Kong SAR and Singapore, and other economies such as China, India and Malaysia in reflection of data availability.

For the dependent variable, we use quarterly portfolio inflows to an EME from the balance of payments (BOP) data normalized by the economy's GDP. The BOP data are comprehensive but the available data frequency is quarterly, while the Emerging Portfolio Fund Research (EPFR) data with information on total assets under management (AUM) at the end of the period and their destinations do not cover all portfolio inflows to an EME but provide daily, weekly and also monthly data. Our empirical model is estimated on the more comprehensive quarterly BOP data.

We have six explicative variables as well as the UMP variables: the interest rate differential, GDP growth differential, VIX, US equity returns, domestic equity returns, and nonresidents' portfolio investment outstanding relative to GDP. Most of these variables are used frequently in the existing literature for the determinants of capital flows to EMEs, although the specific forms or data frequencies vary.5) The interest rate differential between an EME and the US is expected to have a positive effect on portfolio inflows to that EME. The relatively high economic growth of the EME will attract more portfolio investment. An increase in the VIX as a proxy for the level of global risk aversion is known to decrease international portfolio flows to EMEs. Changes in US and EME stock prices will also affect international portfolio flows. Higher existing portfolio investment outstanding in an economy can attract more investment to it as a preferred destination of international investors, while the need for portfolio rebalancing between the economy and other EMEs can result in less investment flows. EPFR equity AUM is used as a proxy for portfolio investment outstanding, as EPFR bond AUM for our full sample period is unavailable. These variables are explained in Table A.1.

It is a bit difficult to determine how to measure the AEs' UMPs for our model. We consider three UMP (or UMP-related) variables in accordance with the existing

5) Please refer to Ahmed and Zlate (2013), Fratzscher et al. (2013), Gauvin et al. (2013), Moore et al. (2013), and Yoon and Kim (2012). 
literature: global liquidity growth, the change in the US 10-year Treasury bond rate, and the growth in security assets of the Fed.6) The first variable is an indirect measure of UMPs while the latter two are direct measures. We need the first one, as it may capture well the ultimate effects of the UMPs on capital flows to EMEs as argued in Yoon and Kim (2012). This is because the UMPs will affect capital flows to EMEs through the private sector credit creation process while AEs' policy rates face zero lower bounds. The quantitatively measured global liquidity covers all credit aggregates in the G3 (the US, the Eurozone and Japan) using flow of funds data and cross-border credit in G3 currencies using the BIS locational banking statistics.7) From another aspect regarding our choices, global liquidity and the Fed's net asset purchases are quantitative measures, while the Treasure yield is a price measure. We need both kinds of measures because their results might not be the same. ${ }^{8)}$

\subsection{Specifications}

One of the main difficulties in modelization of the effects of the UMPs on international portfolio investment flows to EMEs consists in determining the driving forces of this relationship's heterogeneity across countries and also its nonlinearity over time. What are the economic variables that explain the heterogenous effects of the UMPs on portfolio inflows to EMEs? In our PSTR model, this question corresponds to determining the appropriate threshold variable. Here, we consider three "candidates" - the current account relative to GDP (\%), the REER gap (REER deviation from its historical average), and FX reserves relative to GDP (\%).9) Note

6) Fratzscher et al. (2013) measure the UMPs with four sets of data: the Fed's QE announcement in the form of a dummy, the liquidity support for the financial sector, purchases of long-term treasury bonds, and purchases of long-term mortgage backed securities (MBSs). Moore et al. (2013) map Federal Reserve LSAPs with reduced 10-year U.S. Treasury yields to analyze the impacts of the LSAPs on EMEs' bond markets. In this case, the two measures could be used interchangeably for the UMPs.

7) For the calculation of global liquidity we are using Yoon and Kim (2012)'s method, which closely follows the CGFS $(2011,2012)$.

8) The Committee on the Global Financial System (CGFS) $(2011,2012)$ suggests using both quantitative and price indicators for judging global liquidity conditions properly. This implies that these two kinds of indicators could sometimes but not always give researchers similar or complimentary information.

9) The IMF (2013c) analyzes the possible impacts of changes in UMPs on capital flows to non-UMP 
that these three candidates for the threshold variable are time-varying and specific to each country. For each specification the elasticity of our UMP variable $z_{i t}$, that depends on the lagged ${ }^{10)}$ threshold variable, is consequently country-specific and time-varying since we have

$$
e_{i t}^{(z)}=\frac{\delta y_{i t}}{\delta z_{i t}}=\beta_{0}+\sum_{j=1}^{r} \beta_{j} g_{j}\left(q_{i t-1} ; \gamma_{j}, c_{j}\right) \forall i=1, \cdots, N, \forall t=1, \cdots, T
$$

This is an important difference from the methodology of Gauvin et al. (2013), who consider the time index as their threshold variable. In their case, the corresponding elasticities of the policy-related variable, US and EU policy uncertainty, are time-varying, but they neglect the cross-country heterogeneity. Indeed, if the threshold variable corresponds to the time index, i.e. $q_{i t}=q_{t}=t$, the elasticity given by $(15)$ is identical for all countries, i.e. $e_{i t}^{(z)}=e_{i t}^{(z)}$ for $i=1, \cdots, N$. Finally, we have nine specifications from combinations between the three UMP and the three threshold variables. For example, in a first specification, we assume that the threshold variable corresponds to the current account balance relative to GDP, i.e. $q_{i t}=C A_{i t}$. Under this assumption, the elasticity of a UMP variable depends on the current account balance, and as a consequence is country-specific and time-varying.

For each model, the first step is to test the linear specification of the portfolio flows against a specification with threshold effects. If the linearity hypothesis is rejected, the second step will be to determine the number of transition functions required in order to capture all of the non-linearity. The results of these linearity and specification tests with no remaining non-linearities are reported in Table 1 to 3. For each specification, we calculate the LR statistics for the linearity tests

countries. For the analysis, it suggests 16 indicators of exposure and resilience as criteria for measuring the vulnerability of a non-UMP economy in the face of tapering in AEs. We choose six candidates from among these indicators for use as threshold variables in our specifications. Existing nonresidents' portfolio investment outstanding as an exposure of the economy is included as an explicative variable in our model, instead of as a threshold variable which causes a convergence problem. Fiscal balances and government debt outstanding are dropped, however, because the available data frequency is basically annual, and interpolated quarterly data do not work in trying to derive sensible results.

10) Each threshold variable is lagged to decrease the possible endogeneity and also the multicollinearity between the threshold variable and the UMP. 
( $H_{0}: r=0$ versus $H_{1}: r=1$ ) and for the tests of no remaining non-linearity ( $H_{0}: r=a$ versus $\left.H_{1}: a+1\right)$. The values of the statistics are reported up to the first acceptance of $H_{1}$. The linearity tests clearly lead to rejection of the null hypothesis of the linearity of the relationships between the portfolio inflows to EMEs and their determinants. Whatever the specification considered and the choice of dependent variable, according to the $\mathrm{LR}$ statistics the null $H_{0}: r=0$ is strongly rejected. This first result confirms the non-linearity of the relation.

The specification tests of no remaining non-linearity lead to the identification of an optimal number of transition functions in every case. The results of these tests are reported in Table 1 to 3 . The optimal number of transition functions for all is equal to one. In other words, in a PSTR model a small number of extreme regimes is sufficient for capturing the crosssectional- and time-variability of the slope parameters (elasticities). However, we should recall that a smooth transition model, even with two extreme regimes $(r=1)$, can be viewed as a model with an infinite number of intermediate regimes. The elasticities are defined at each quarter and for each country as weighted averages of the values obtained in the two extreme regimes. The weights depend on the value of the transition function. And so, even if $r=1$, this model will allow a "continuum" of values (or regimes) for the elasticities, each one associated with a different value of the transition function $\mathrm{g}($. between 0 and 1 .

\section{Main Results}

\section{Effects of Global Liquidity Growth on Portfolio Inflows to EMEs}

To the extent that the UMPs undertaken in AEs directly and/or indirectly prop up global liquidity, we use global liquidity as a good proxy for the UMPs. An increase in global liquidity growth generally increases portfolio inflows to EMEs, as shown in Table 1. This is consistent with the results in Table A.2 and with Yoon and 


\section{$15 \quad$ BOK Working Paper No.2014-05 (2014.03)}

Table 1: Effects of Global Liquidity Growth on Portfolio Inflows to EMEs

\begin{tabular}{|c|c|c|c|c|c|c|}
\hline \multirow{3}{*}{ Threshold Variables } & \multicolumn{6}{|c|}{ Dependent: Portfolio inflows } \\
\hline & \multicolumn{2}{|c|}{ L.CA } & \multicolumn{2}{|c|}{ L.REER_gap } & \multicolumn{2}{|c|}{ L.FX_reserve } \\
\hline & $\beta_{0}$ & $\beta_{1}$ & $\beta_{0}$ & $\beta_{1}$ & $\beta_{0}$ & $\beta_{1}$ \\
\hline \multirow[t]{2}{*}{ ir_diff } & 0.0576 & -0.0144 & 0.0445 & 0.1236 & 0.0586 & 0.0408 \\
\hline & $(0.0593)$ & $(0.0662)$ & $(0.0270)$ & $(0.0516)$ & $(0.0301)$ & $(0.0704)$ \\
\hline \multirow[t]{2}{*}{ GDP_diff } & 0.3239 & -0.2528 & 0.0804 & 0.0375 & -0.0350 & 0.1536 \\
\hline & $(0.1821)$ & $(0.1948)$ & $(0.1010)$ & $(0.1124)$ & $(0.0673)$ & $(0.1157)$ \\
\hline \multirow[t]{2}{*}{ vix } & -0.1483 & 0.0926 & -0.0575 & -0.0179 & -0.0639 & -0.0032 \\
\hline & $(0.0771)$ & $(0.0763)$ & $(0.0197)$ & $(0.0204)$ & $(0.0238)$ & $(0.0259)$ \\
\hline \multirow[t]{2}{*}{ US_equity_return } & 0.0917 & -0.0030 & 0.0394 & 0.1352 & 0.0756 & 0.0508 \\
\hline & $(0.1853)$ & $(0.1859)$ & $(0.0297)$ & $(0.0526)$ & $(0.0302)$ & $(0.0462)$ \\
\hline \multirow[t]{2}{*}{ L.dom_equity_return } & -0.0332 & 0.0194 & -0.0177 & 0.0101 & -0.0321 & 0.0282 \\
\hline & $(0.0544)$ & $(0.0550)$ & $(0.0100)$ & $(0.0217)$ & $(0.0108)$ & $(0.0178)$ \\
\hline \multirow[t]{2}{*}{ L.epfr_equity } & -0.0365 & 0.0737 & 0.0281 & -0.0129 & 0.1164 & -0.1232 \\
\hline & $(0.0844)$ & $(0.0843)$ & $(0.0271)$ & $(0.0219)$ & $(0.0456)$ & $(0.0499)$ \\
\hline \multirow[t]{2}{*}{ gl_growth } & 0.5012 & -0.4234 & 0.1541 & -0.1311 & 0.0983 & 0.0027 \\
\hline & $(0.3722)$ & $(0.3751)$ & $(0.0659)$ & $(0.1142)$ & $(0.0671)$ & $(0.1064)$ \\
\hline \multicolumn{7}{|l|}{ Transition Function } \\
\hline No. of transition functions & \multicolumn{2}{|c|}{1} & \multicolumn{2}{|c|}{1} & \multicolumn{2}{|c|}{1} \\
\hline Slope parameters & \multicolumn{2}{|c|}{380.2249} & \multicolumn{2}{|c|}{3.1505} & \multicolumn{2}{|c|}{10.8650} \\
\hline Location Parameters & \multicolumn{2}{|c|}{-7.2831} & \multicolumn{2}{|c|}{4.1675} & \multicolumn{2}{|c|}{66.2079} \\
\hline \multicolumn{7}{|l|}{ Diagnostic } \\
\hline Observations & \multicolumn{2}{|c|}{765} & \multicolumn{2}{|c|}{765} & \multicolumn{2}{|c|}{765} \\
\hline Mean of F.E. & \multicolumn{2}{|c|}{1.8346} & \multicolumn{2}{|c|}{1.8293} & \multicolumn{2}{|c|}{1.9239} \\
\hline RSS & \multicolumn{2}{|c|}{6889.9284} & 6977 & 0697 & 6918 & 6017 \\
\hline AIC & 2.2 & & 2.2 & 542 & 2.2 & 457 \\
\hline $\mathrm{BIC}$ & 2.3 & & 2.3 & & 2.3 & 413 \\
\hline Linearity Tests & & & & & & \\
\hline LR Linearity test & 5.9 & & 11.7 & 439 & 6.9 & 283 \\
\hline$p$-value & 0.0 & & 0.0 & 000 & & 000 \\
\hline LR test : H0 $: r=1$ vs $\mathrm{H} 1: r=2$ & 10.6 & 069 & 4.7 & 251 & 7.9 & 013 \\
\hline$p$-value & 0.1 & & 0.6 & 935 & & 414 \\
\hline
\end{tabular}

Note: 1) The values in parentheses are standard errors corrected for heteroskedasticity. Refer to Table A.1 for descriptions of the variables.

Source: Authors' estimations 
Kim (2012)'s findings. However, global liquidity turns out to affect EMEs differently depending upon fundamentals or so-called pull factors in the EMEs concerned such as their current accounts, REER gaps, and FX reserves. These individual economy pull factors seem to drive heterogeneity in the effects of UMPs on portfolio inflows to EMEs over time.

\subsection{Current Account}

The elasticity of the portfolio inflows in response to global liquidity growth ranges between $0.5012\left(\beta_{0}\right)$ and $0.0778\left(\beta_{0}+\beta_{1}\right)$. Moreover, an increase in portfolio inflows due to an acceleration in global liquidity growth is further intensified when the value of the current account relative to GDP is less than $-7.3 \%$, since $\left.\beta_{1}<0.11\right)$ This result is consistent with the negative balance of payments relationship between the current account and financial account balances with the foreign exchange reserves fixed. However, the number of observations with current account-to-GDP ratios of less than $-7.3 \%$ accounts for only $3.7 \%$ of the 300 total observations from 2007.Q4 to 2012.Q3. Economies with relatively severe current account deficits thus see greater benefits from more abundant global liquidity due to AEs' QE, while getting hurt more from a contraction in global liquidity.

The lefthand side of Figure 3 displays the recent five-year average elasticities ${ }^{12)}$ estimated for the 15 economies of the panel. Their average elasticities are displayed together with their current accounts normalized by GDP averaged over the same period. We verify that the elasticity increases in rare cases with severely negative current account balances, while the elasticities among the other economies are almost the same as predicted in Table 1. The righthand side of Figure 3 illustrates the time variability of the impacts of the UMPs. It displays the cross-sectional average of the 15 economies' portfolio inflow elasticities with respect to the rate of global liquidity growth, reported between 2000.Q1 and 2012.Q4. We can observe that the positive effect of global liquidity seems not to change. This is due to the

11) Since the estimated slope parameter (380.2) is very large, the elasticity at each time t takes only two values: 0.5012 if the current account is smaller than $-7.3 \%$ (estimated location parameter), or 0.0778 if it is higher.

12) The change of the period considered for calculating the average elasticity does not affect the findings. 
Figure 3: Elasticity of Portfolio Inflows to EMEs with Respect to Global Liquidity Growth, as a Function of the Current Account ${ }^{1)}$
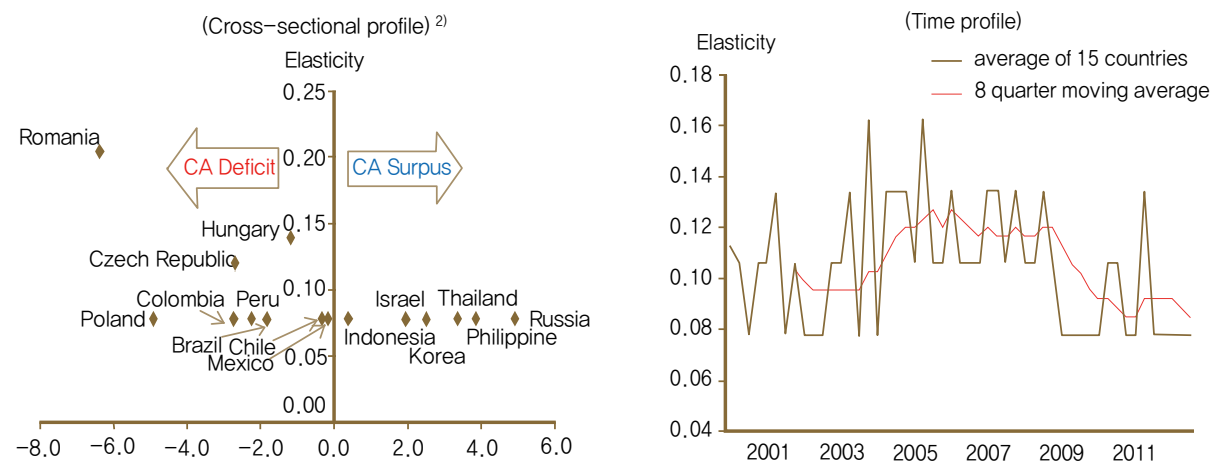

Notes: 1) Portfolio inflows and current account scaled by each economy's quarterly GDP

2) Based on average of last five years (2008.Q1-2012.Q4) for each economy

Source: Authors' calculations

fact that a slight change in an EME's current account ${ }^{13)}$ does not affect the elasticity, as explained above.

These estimation results imply that, if global liquidity growth is negatively affected in the face of $\mathrm{QE}$ tapering or exit, portfolio inflows to EMEs with severe current account deficits will contract more. However, global liquidity as a whole does not contract, thanks to AEs' economic recoveries and consequent rising private sector credit creation in line with increased risk appetites, and therefore the effects of contractionary UMPs on EMEs could be a 'typhoon in a tea cup.' This outlook would be more proper for an EME with a higher current account surplus.

\subsection{REER Gap}

When the threshold variable is the REER gap, an economy with an already highly appreciated exchange rate will experience relatively low portfolio inflows even despite an increase in the rate of global liquidity growth. To be specific, as the REER gap increases close to and becomes higher than 4.2 (estimated location parameter), the elasticity of international portfolio investment in response to

13) The changes in average current account-to-GDP ratios of the 15 economies are depicted in Figure A.1. 
global liquidity growth decreases down to $0.0230\left(\beta_{0}+\beta_{1}\right)$, as shown in Table $\left.1 .{ }^{14}\right)$ Since $\beta_{1}$ is negative, the elasticity falls with the REER gap. In contrast, when the exchange rate has already been relatively depreciated, the elasticity of the portfolio inflows with respect to the global liquidity growth rate is positive and equal to $0.1541\left(\beta_{0}\right)$. The elasticity of an economy at each time $t$ takes different values between 0.1541 and 0.0230 with the relatively smaller estimated slope parameter, 3.2.

The lefthand side of Figure 4 shows that the positive effect of global liquidity on portfolio inflows to EMEs is strengthened as a country's exchange rate depreciates more relative to its historical average. This might be related to an increase in the expected rate of return, since with a depreciated currency the possibility of appreciation may increase. Moreover, this figure clearly illustrates the cross-country heterogeneity of the impacts of the UMPs. Since the REERs of EMEs have risen during the recent few years, as seen on Figure A.1, the degree of the positive effect of global liquidity on portfolio investment into EMEs through the REER gap has weakened, as seen in the righthand side of Figure 4. This figure also verifies the time-variability of the impacts of the UMPs.

Figure 4: Elasticity of Portfolio Inflows to EMEs with Respect to Global Liquidity Growth, as a Function of the REER Gap ${ }^{1)}$
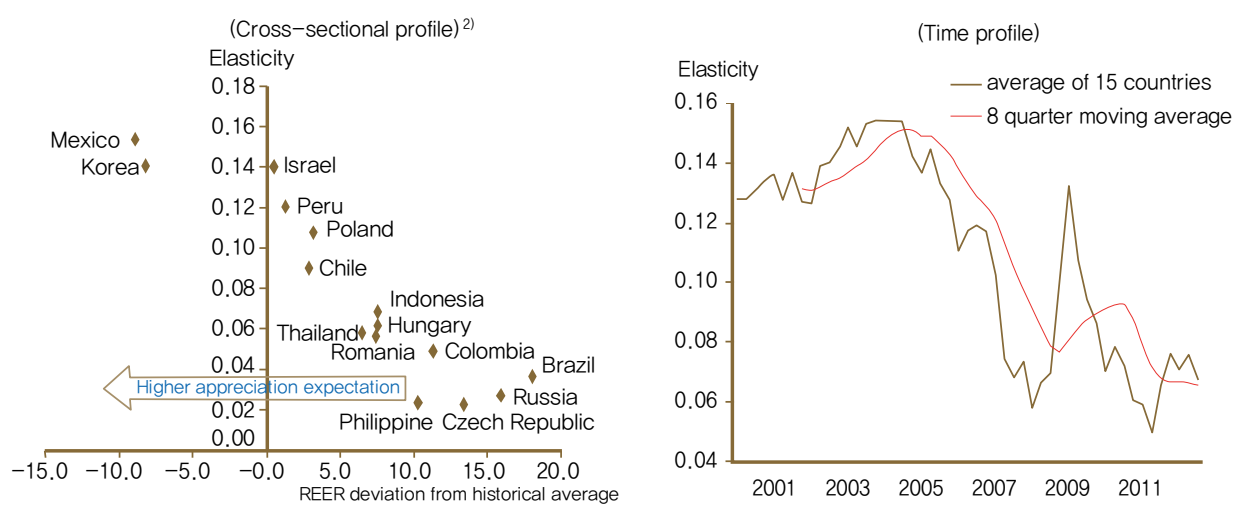

Notes: 1) REER gap is REER deviation from its historical average

2) Same as Note 2) in Figure 3

Source: Authors' calculations

14) The number of observations higher than the REER gap threshold level, 4.2 , amounts to $59.3 \%$ of the 300 total observations from 2007.Q4 to 2012.Q3. 


\subsection{FX Reserves}

We also find weak cross-country heterogeneity and time-variability of the impacts of global liquidity growth when foreign exchange (FX) reserves relative to quarterly GDP are the threshold variable for the model specification. Concerning interpretation of the estimation results, we consider the elasticity of portfolio inflows in response to global liquidity growth in Table 1 and on Figure 5 . To be specific, as FX reserves become bigger relative to an economy's size, the elasticity of portfolio inflows in response to global liquidity growth increases slightly since $\beta_{1}$ is positive and equal to 0.0027.15) For example, the elasticity of Mexico, with the lowest FX reserves-to-quarterly GDP ratio $(10.6 \%)$, is 0.0983 , while that of Thailand, with the highest $(181.8 \%)$, is 0.1010 , as seen in the lefthand side of Figure 5. The overall sensitivity of portfolio inflows to EMEs has increased slightly since 2005. This is mainly because the average FX reserves-to-quarterly GDP ratio of the 15 sample economies has risen from $63.6 \%$ in 2005 to $91.7 \%$ in 2012, as shown in Figure A.1 in the Appendix.

\section{Figure 5: Elasticity of Portfolio Inflows to EMEs with Respect to Global} Liquidity Growth, as a Function of FX Reserves ${ }^{1)}$
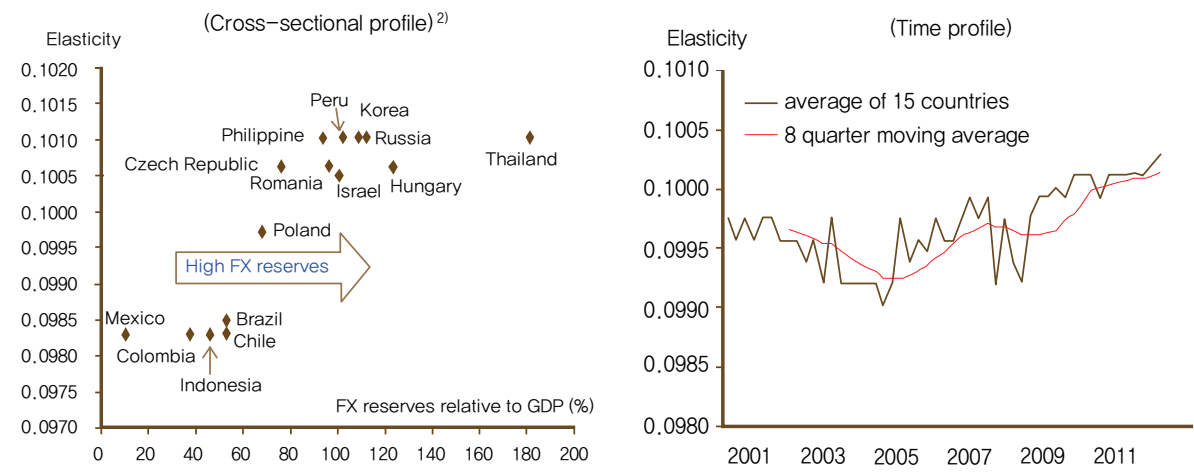

Notes: 1) FX reserves scaled by quarterly GDP

2) Same as Note 2) in Figure 3

Source: Authors' calculations

15) The threshold level of the FX reserves-to-GDP ratio is $66.2 \%$. I.e., when it is higher than this level the elasticity of portfolio inflows to an economy generally becomes a bit greater - from 0.0983 to 0.1010 as shown in Table 1. The number of observations with FX reserves-to-GDP ratios higher than $66.2 \%$ accounts for $59.7 \%$ of the 300 total observations from 2007.Q4 to 2012.Q3. 
As Ahmed and Zlate (2013) state, more FX reserves as a precautionary buffer against any external shocks may contribute to international investors' confidence in the economy and subsequent larger investment in it. This is just one side of the coin concerning the effects of higher elasticity, which is valid only under a positive UMP shock. Even though one economy has a good environment for investment, with greater holdings of FX reserves, a higher elasticity implies that it will experience a larger reduction in portfolio inflows to it in the face of a negative global shock such as the GFC. Investors are likely to decrease their exposures to EMEs proportionally when a global shock is generated from outside of EMEs.

From the perspective of financial stability, an economy preferred by investors due to its larger FX reserves, higher currency appreciation expectations, and/or own need of funding reflected in a severe current account deficit will experience sudden stops or reversals of portfolio inflows in the face of a negative UMP shock. In other words, the economy could become a so-called innocent bystander victim. This is in line with Furceri et al. (2011), who argue that large capital inflows increase the likelihood of currency crises and sudden stops. ${ }^{16)}$

\section{Effects of Growth in Fed's Security Assets on Portfolio Inflows to EMEs}

Now we consider the Fed's net security purchases as a more direct quantitative measure of UMPs compared with global liquidity growth. The data span is shorter, however, since the data on Fed security asset growth starts from the $4^{\text {th }}$ quarter of 2007. We find very similar patterns of cross-sectional heterogeneity and time variability of the elasticity for the REER gap and FX reserves as threshold variables by comparing Figure 6 with Figures 4 and 5 . In contrast, their patterns for the current account as the threshold variable are the opposite. Despite these qualitative similarities and dissimilarities of the results for the two UMP variables, the elasticity of portfolio inflows to EMEs looks more homogenous as well as smaller in its magnitude in response to growth in the Fed's security assets, given the smaller

16) They go further to argue that debt-driven large capital inflows increase the probability of crises, while equity or FDI have negligible effects. 
coefficients $\left(\beta_{0}\right)$ and smaller differences between its maximum and minimum values. This could be due to the fact that the indirect measure, global liquidity, includes all of the information including the private sector credit creation process, and tends to be affected with the passage of time by the direct UMPs. If we look at this from a different angle, we could say that it takes time for the UMPs to have their full effects on portfolio inflows to EMEs.

Detailed interpretations of Table 2 and Figure 6 could be done in the same manner as in the previous subsection. However, we only highlight some of the results: First, given the threshold variable's $-7.8 \%$ location parameter in Table 2, international investors tend to adjust their portfolio investments in EMEs in the same manner and with similar magnitudes in response to Fed security asset growth, as long as the EMEs do not record serious current account deficits. ${ }^{17)}$ This is due to the possibility that more liquidity supplied by the Fed will crowd out the investment instruments available for private sector investors, and/or lower the rates of return in the AEs' markets.

Second, the elasticity of portfolio inflows to an economy with a severe current account deficit is slightly smaller than the elasticities of inflows to other economies for Fed security asset growth as the direct quantitative UMP measure, while the reverse is true for the indirect quantitative UMP measure, global liquidity growth, as mentioned above. This implies that international investors are in response to an increase in quantitatively measured UMP initially reluctant to invest in an economy with a serious current account deficit, but later increase their investments in that economy, possibly due to its external funding needs, the search for yield, and/or scarcer investment instruments in other economies. However, it is not certain that the estimation results' prediction of milder outflows of portfolio investment from the economy with serious current account deficit is realized in the phase of contraction in the Fed's security assets. This is because the data on the Fed's security assets covers only their expansionary phase of from 2007.Q4 to 2012.Q4.

17) The number of observations with current accounts below the threshold level of $-7.8 \%$ is 10 , which is $3.3 \%$ of the 300 total observations made from 2007.Q4 to 2012.Q3. 
Table 2: Effects of Fed Security Asset Growth on Portfolio Inflows to EMEs

\begin{tabular}{|c|c|c|c|c|c|c|}
\hline \multirow{2}{*}{ Threshold Variables } & \multicolumn{2}{|c|}{ L.CA } & \multicolumn{2}{|c|}{ L.REER_gap } & \multicolumn{2}{|c|}{ L.FX_reserve } \\
\hline & $\beta_{0}$ & $\beta_{1}$ & $\beta_{0}$ & $\beta_{1}$ & $\beta_{0}$ & $\beta_{1}$ \\
\hline \multirow[t]{2}{*}{ ir_diff } & -1.2893 & 1.3228 & 0.0050 & -0.2919 & -0.0094 & -0.2112 \\
\hline & $(0.4923)$ & $(0.4869)$ & $(0.1018)$ & $(0.1795)$ & $(0.1099)$ & $(0.4345)$ \\
\hline \multirow[t]{2}{*}{ GDP_diff } & 0.5672 & -0.4507 & 0.0887 & 0.2773 & 0.1206 & -0.2130 \\
\hline & $(0.1885)$ & $(0.1939)$ & $(0.0517)$ & $(0.1565)$ & $(0.0599)$ & $(0.1116)$ \\
\hline \multirow[t]{2}{*}{ vix } & 0.1048 & -0.2070 & -0.0914 & -0.0408 & -0.1100 & -0.1156 \\
\hline & $(0.1232)$ & $(0.1213)$ & $(0.0326)$ & $(0.0346)$ & $(0.0385)$ & $(0.0682)$ \\
\hline \multirow[t]{2}{*}{ US_equity_return } & 0.0890 & -0.0150 & 0.0703 & 0.2329 & 0.0929 & -0.1429 \\
\hline & $(0.1223)$ & $(0.1162)$ & $(0.0423)$ & $(0.0977)$ & $(0.0408)$ & $(0.1095)$ \\
\hline \multirow[t]{2}{*}{ L.dom_equity_return } & -0.1145 & 0.1100 & 0.0021 & -0.1436 & -0.0007 & -0.0172 \\
\hline & $(0.0624)$ & $(0.0637)$ & $(0.0161)$ & $(0.0606)$ & $(0.0165)$ & $(0.0525)$ \\
\hline \multirow[t]{2}{*}{ L.epfr_equity } & -1.1510 & 1.1527 & 0.0149 & 0.1133 & -0.0054 & 0.0406 \\
\hline & $(0.3890)$ & $(0.3850)$ & $(0.0435)$ & $(0.0415)$ & $(0.0468)$ & $(0.0737)$ \\
\hline \multirow[t]{2}{*}{ Fed_secu_growth } & 0.0129 & 0.0048 & 0.0157 & -0.1262 & 0.0197 & 0.0255 \\
\hline & $(0.0343)$ & $(0.0365)$ & $(0.0119)$ & $(0.0795)$ & $(0.0130)$ & $(0.0388)$ \\
\hline \multicolumn{7}{|l|}{ Transition Function } \\
\hline No. of transition functions & \multicolumn{2}{|c|}{1} & \multicolumn{2}{|c|}{1} & \multicolumn{2}{|c|}{1} \\
\hline Slope parameters & \multicolumn{2}{|c|}{355.9841} & \multicolumn{2}{|c|}{143.4280} & \multicolumn{2}{|c|}{8283.5716} \\
\hline Location Parameters & \multicolumn{2}{|c|}{-7.7969} & \multicolumn{2}{|c|}{18.8642} & \multicolumn{2}{|c|}{126.9751} \\
\hline \multicolumn{7}{|l|}{ Diagnostic } \\
\hline Observations & \multicolumn{2}{|c|}{315} & \multicolumn{2}{|c|}{315} & \multicolumn{2}{|c|}{315} \\
\hline Mean of F.E. & \multicolumn{2}{|c|}{3.5750} & \multicolumn{2}{|c|}{3.2737} & \multicolumn{2}{|c|}{4.2549} \\
\hline RSS & \multicolumn{2}{|c|}{2435.8301} & \multicolumn{2}{|c|}{2492.3586} & 2501 & 0085 \\
\hline AIC & 1.2 & & 1.2 & & & 82 \\
\hline $\mathrm{BIC}$ & 1.2 & & 1.3 & & & \\
\hline Linearity Tests & & & & & & \\
\hline LR Linearity test & 7.4 & & 8.0 & & & 174 \\
\hline p-value & 0.0 & 00 & 0.0 & & & 00 \\
\hline LR test : H0 $: r=1$ vs $\mathrm{H} 1: r=2$ & 2.9 & & 8.4 & & 11. & 117 \\
\hline$p$-value & & & & & & \\
\hline
\end{tabular}

Note: 1) Same as Note 1) in Table 1

Source: Authors' estimations 
Figure 6: Elasticity of Portfolio Inflows to EMEs with Respect to Fed Security Asset Growth, as a Function of..."
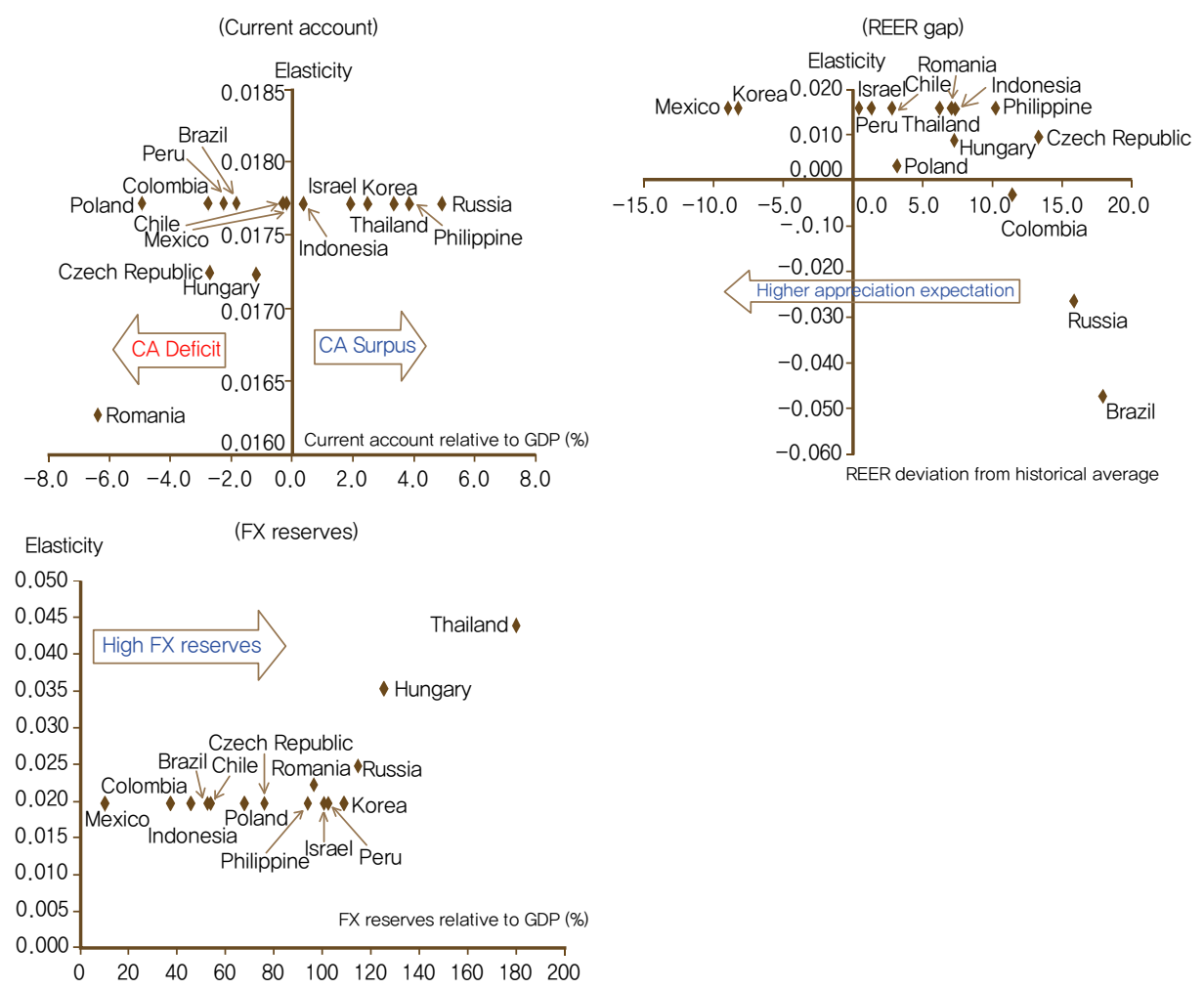

Note: 1) Same as Note 2) in Figure 3

Source: Authors' calculations

Third, as the Fed increases its security assets through the LSAPs, an economy whose currency is relatively more depreciated from its historical average faces more portfolio inflows, as shown in the upper righthand side of Figure 6. Fourth, if an economy accumulates more FX reserves relative to GDP, it sees more portfolio inflows in response to the Fed's LSAPs. 


\section{Effects of US 10-year T-bond Yield on Portfolio Inflows to EMEs}

With a price variable, a long-term US interest rate, as a measure of UMPs, we find a quite different story about the pattern of heterogeneity in the elasticity of portfolio inflows across countries in Table 3 and in Figures 7, 8, and 9. The size of the negative elasticity with respect to a change in the US 10-year T-bond rate decreases when there is an increase in the current account, a decrease in the REER gap, or an increase in FX reserves. These results are the opposite of those in the cases where the direct quantitative measure of UMPs, growth in the Fed's security assets, was used, as explained in the previous subsection. To reconcile these somewhat seemingly contradictory outcomes, we need to specify the differences that exist between the price and the quantitative variable.

Price variables such as exchange rates, stock prices and interest rates tend to react very quickly in response to news or changes in market sentiments. For example, the US 10-year T-bond rate increased by about 90 basis points ${ }^{18}$ ) in response to news about and expectations of possible $\mathrm{QE}$ tapering from mid-May to mid-August in 2013, while the quantitative measure of the Fed's security assets actually has not changed yet. In line with this, the correlation between changes in the US 10-year Treasury rate and Fed security asset growth is just 0.33 during 2007.Q4-2012.Q4. This difference between the price and the quantitative variables seems to be behind the differences in UMP impacts on portfolio inflows to EMEs that we have found. In a nutshell, if an EME has resilient fundamentals, such as a higher current account balance, a less appreciated real exchange rate, and a higher level of FX reserves, portfolio inflows to the economy will show stronger resilience in response to a change in US long-term yields, an international market price variable.

Another noticeable difference exists between the direct price UMP measure (change in US long-term interest rates), the direct quantitative UMP measure (growth in Fed security assets), and the indirect quantitative measure (global liquidity growth), when it comes to location parameter estimates with the REER gap

18) This is substantially large, given that the total effects of LSAP1 and LSAP2 on the yields is 113 basis points, based on the median estimates in the related literature. Refer to Moore et al. (2013). 


\section{$25 \quad$ BOK Working Paper No.2014-05 (2014.03)}

Table 3: Effects of Changes in US 10-year Treasury Rate on Portfolio Inflows to EMEs

\begin{tabular}{|c|c|c|c|c|c|c|}
\hline \multirow{3}{*}{ Threshold Variables } & \multicolumn{6}{|c|}{ Dependent: Portfolio inflows } \\
\hline & \multicolumn{2}{|c|}{ L.CA } & \multicolumn{2}{|c|}{ L.REER_gap } & \multicolumn{2}{|c|}{ L.FX_reserve } \\
\hline & $\beta_{0}$ & $\beta_{1}$ & $\beta_{0}$ & $\beta_{1}$ & $\beta_{0}$ & $\beta_{1}$ \\
\hline ir_diff & $\begin{array}{l}0.0504 \\
(0.0646)\end{array}$ & $\begin{array}{l}-0.0058 \\
(0.0705)\end{array}$ & $\begin{array}{c}0.0236 \\
(0.0318)\end{array}$ & $\begin{array}{c}0.1406 \\
(0.0453)\end{array}$ & $\begin{array}{c}0.0563 \\
(0.0300)\end{array}$ & $\begin{array}{c}0.0492 \\
(0.0700)\end{array}$ \\
\hline GDP_diff & $\begin{array}{c}0.3747 \\
(0.1849)\end{array}$ & $\begin{array}{l}-0.2964 \\
(0.1979)\end{array}$ & $\begin{array}{l}-0.1688 \\
(0.0878)\end{array}$ & $\begin{array}{c}0.3474 \\
(0.1200)\end{array}$ & $\begin{array}{l}-0.0254 \\
(0.0661)\end{array}$ & $\begin{array}{c}0.1530 \\
(0.1149)\end{array}$ \\
\hline vix & $\begin{array}{l}-0.1190 \\
(0.0729)\end{array}$ & $\begin{array}{c}0.0592 \\
(0.0713)\end{array}$ & $\begin{array}{l}-0.0428 \\
(0.0212)\end{array}$ & $\begin{array}{l}-0.0419 \\
(0.0197)\end{array}$ & $\begin{array}{l}-0.0645 \\
(0.0241)\end{array}$ & $\begin{array}{l}-0.0087 \\
(0.0259)\end{array}$ \\
\hline US_equity_return & $\begin{array}{c}0.2563 \\
(0.1370)\end{array}$ & $\begin{array}{l}-0.1476 \\
(0.1378)\end{array}$ & $\begin{array}{c}0.0878 \\
(0.0491)\end{array}$ & $\begin{array}{c}0.0393 \\
(0.0548)\end{array}$ & $\begin{array}{c}0.1068 \\
(0.0307)\end{array}$ & $\begin{array}{c}0.0457 \\
(0.0471)\end{array}$ \\
\hline L.dom_equity_return & $\begin{array}{l}-0.0139 \\
(0.0517)\end{array}$ & $\begin{array}{c}0.0040 \\
(0.0525)\end{array}$ & $\begin{array}{l}-0.0094 \\
(0.0163)\end{array}$ & $\begin{array}{c}0.0022 \\
(0.0196)\end{array}$ & $\begin{array}{l}-0.0278 \\
(0.0106)\end{array}$ & $\begin{array}{c}0.0285 \\
(0.0174)\end{array}$ \\
\hline L.epfr_equity & $\begin{array}{l}-0.0517 \\
(0.0738)\end{array}$ & $\begin{array}{c}0.0842 \\
(0.0747)\end{array}$ & $\begin{array}{c}0.0304 \\
(0.0371)\end{array}$ & $\begin{array}{l}-0.0281 \\
(0.0346)\end{array}$ & $\begin{array}{c}0.1098 \\
(0.0447)\end{array}$ & $\begin{array}{l}-0.1212 \\
(0.0495)\end{array}$ \\
\hline d_US_t_bond_10yr & $\begin{array}{r}-1.0939 \\
(2.2189)\end{array}$ & $\begin{array}{c}0.7096 \\
(2.2533)\end{array}$ & $\begin{array}{c}0.6493 \\
(0.8098)\end{array}$ & $\begin{array}{r}-1.3619 \\
(0.9193)\end{array}$ & $\begin{array}{l}-0.5321 \\
(0.4311)\end{array}$ & $\begin{array}{c}0.0367 \\
(0.7839)\end{array}$ \\
\hline $\begin{array}{l}\text { Transition Function } \\
\text { No. of transition functions } \\
\text { Slope parameters } \\
\text { Location Parameters }\end{array}$ & $\begin{array}{l}442 . \\
-7 .\end{array}$ & $\begin{array}{l}3626 \\
794\end{array}$ & $\begin{array}{r}4106 \\
-10\end{array}$ & $\begin{array}{l}6153 \\
7381\end{array}$ & $\begin{array}{l}3.6 \\
66 .\end{array}$ & $\begin{array}{l}687 \\
782\end{array}$ \\
\hline $\begin{array}{l}\text { Diagnostic } \\
\text { Observations }\end{array}$ & & & & & & 5 \\
\hline Mean of F.E. & & 952 & & & & 882 \\
\hline RSS & 6932 & 0809 & 6934 & 2493 & 6930 & 6943 \\
\hline AlC & & & & 480 & & 475 \\
\hline $\mathrm{BIC}$ & & 433 & & 436 & & 431 \\
\hline Linearity Tests & & & 11 & & & \\
\hline$p$-value & & & & 000 & & 000 \\
\hline LR test : H0: $r=1$ vs $\mathrm{H} 1: r=2$ & & 924 & 15. & 817 & & 277 \\
\hline$p$-value & & & & & & 566 \\
\hline
\end{tabular}

Note: 1) Same as Note 1) in Table 1

Source: Authors' estimations 
Figure 7: Elasticity of Portfolio Inflows to EMEs with Respect to Changes in US 10-year T-bond Rate, as a Function of the Current Account
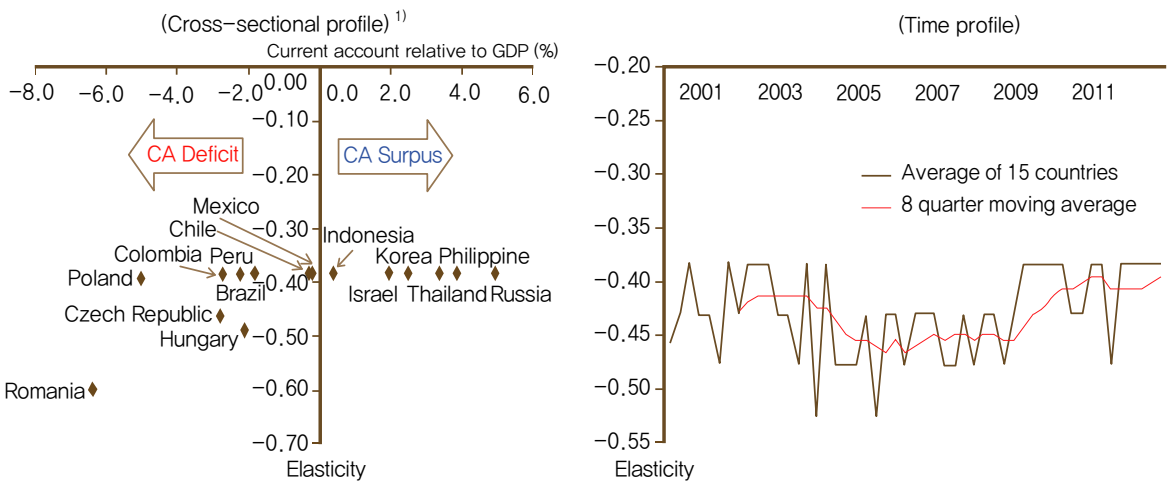

Notes: 1) Same as Note 2) in Figure 3

Source: Authors' calculations

Figure 8: Elasticity of Portfolio Inflows to EMEs with Respect to Changes in US 10-year T-bond Rate, as a Function of the REER Gap
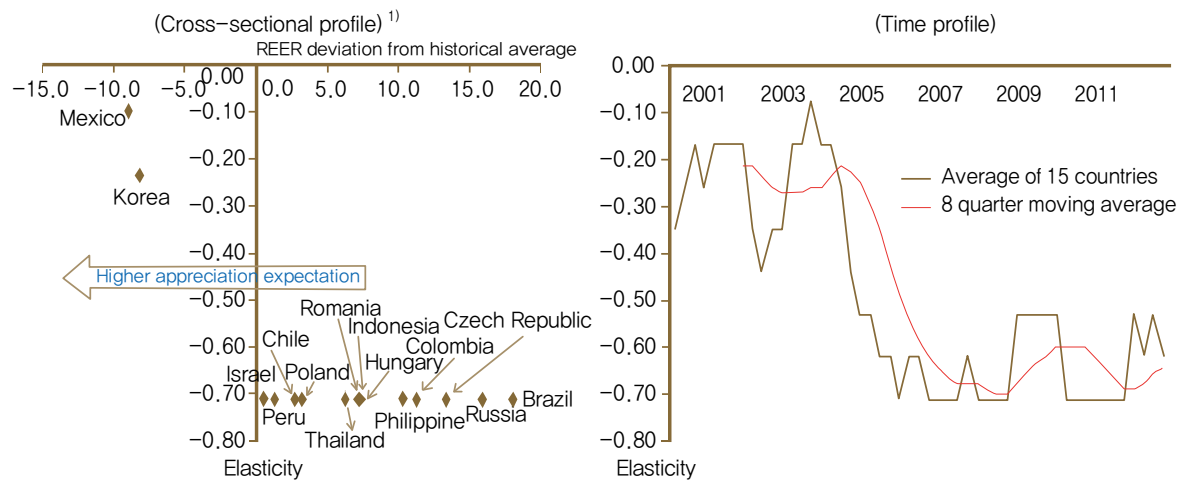

Notes: 1) Same as Note 2) in Figure 3

Source: Authors' calculations 
Figure 9: Elasticity of Portfolio Inflows to EMEs with Respect to Changes in US 10-Year T-bond Rate, as a Function of FX Reserves

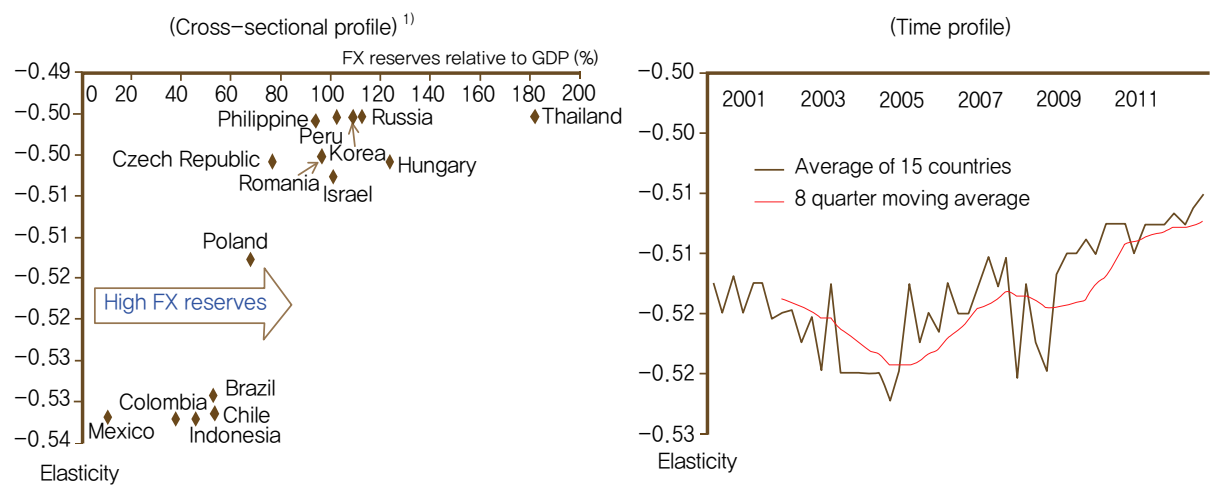

Notes: 1) Same as Note 2) in Figure 3

Source: Authors' calculations

as the threshold variable. The estimated location parameter of US long-term rates, -10.7, implies that only substantially higher appreciation expectations ${ }^{19)}$ can mitigate the sensitivity of portfolio investment in the economy in the face of a price UMP shock, as shown in Table 3. The location parameter estimate of 18.9 for the direct quantitative UMP measure 20 ) implies that foreign investors adjust their assets in EMEs with different sensitivities in response to a UMP shock in the short-run only if the EMEs have substantially appreciated REERs relative to their historical averages. In contrast, the location parameter of 4.2 for the indirect quantitative measure21) tells us that the elasticities of foreign portfolio investment in response to a UMP shock in the long-run change at the level of a mildly appreciated REER. Thus, the initial lower differentiation would be followed as time passes by greater differentiation among EMEs in the sensitivities of portfolio flows to them in response to UMP shocks. This result comes from the fact that the two direct UMP measures, of changes in long-term rates and in the growth in security assets of the

19) The number of observations with location parameters of less than -10.7 amounts to $5.3 \%$ of the 300 total observations from 2007.Q4 to 2012.Q3.

20) The number of observations with estimated parameters at above 18.9 is $8.0 \%$ of the 300 total observations from 2007.Q4 to 2012.Q3

21) The number of observations with parameters greater than 4.2 is $59.3 \%$ of the 300 total observations from 2007.Q4 to 2012.Q3. 
Fed, are relatively immediate or more rapid indicators than the indirect UMP measure of global liquidity growth.

\section{Conclusions}

We find that since the GFC there have been cross-country heterogeneous and time-varying effects of AEs' UMPs on portfolio inflows to EMEs. The current account, the REER gap, and FX reserves turn out to be the drivers of these two dimensional nonlinearities.

The elasticity of portfolio inflows to an EME with respect to a directly quantitatively measured UMP, the Fed's net security asset purchases, increases with an increase in the current account, a decrease in the REER gap (higher appreciation expectation), or an increase in FX reserves. In other words, a better economic environment of an EME induces more inflows of foreign portfolio investment (FPI) in response to a positive "quantitative UMP shock" in the short-run, while since the data covers only the phase of Fed security asset expansion it is uncertain whether the economy experiences more outflows of FPI in response to a negative quantitative UMP shock.

In contrast, the elasticity of FPI to an EME with respect to a direct price measure of UMP such as US long-term Treasury yields becomes smaller with a higher current account balance, a lower REER gap, and bigger FX reserves. To put this differently, an EME with more favorable external sector indicators has stronger resilience to a "price UMP shock". However, an EME with a substantial current account deficit has a higher elasticity with respect to the indirect quantitative UMP measure, global liquidity growth, whose result is different from that for the direct quantitative UMP measure. This seems to be due both to possible differentiation among EMEs with the passage of time after a negative quantitative UMP shock, and to the economy's own funding needs from the balance of payments relation after a positive shock.

With these results, we finally come up with some possible answers to our last question in the introduction about the effects of future exit policies in AEs on 
portfolio inflows to EMEs. Based upon our findings, we need to differentiate a price UMP shock from a quantitative UMP shock. A price shock from news about or impending QE tapering will more adversely affect an EME with relatively fragile fundamentals in its external sector. Some EMEs seem to have experienced this effect in around mid-2013 when the Fed chairman commented about a policy transition. A quantitative UMP shock from actual QE tapering, measured by growth in the Fed's security assets, is expected to reduce FPI flows to EMEs in general, although because of data limitations it is unclear based simply of the estimation results that it will more adversely affect EMEs with better external sectors. However, we can argue that a clearer increase in global liquidity growth due to world economic recovery and financial activities with higher risk appetite is expected to offset the negative effects of actual QE tapering or exits from UMPs. The positive effect of global liquidity growth could more greatly benefit an EME with a substantial current account deficit and consequent strong external funding needs, while also being bigger for economies with more depreciated real exchange rates and higher FX reserves.

Despite the insights gained from the analysis in this paper, our model cannot give any clear prospects for international investors' herding, contagion among EMEs, or the consequent financial market turmoil in a small open EME following UMP shocks from AEs. It is however clear that all of the above findings justify EMEs' macroprudential policies, including capital flow management (CFMs),22) to dampen the negative effects of changes in AE monetary policies.

22) Refer to IMF (2013a) and IMF (2013b). 


\section{References}

Ahmed, S. and A. Zlate (2013), "Capital Flows to Emerging Market Economies: A Brave New World?", Board of Governors of the Federal Reserve System International Finance Discussion Papers, No. 1081.

Committee on the Global Financial System (2011), "Global Liquidity - Concept, Measurement and Policy Implications," CGFS Papers, No. 37.

Committee on the Global Financial System (2012), "Global Liquidity Indicators", prepared for a working group discussion.

Colletaz G. and C. Hurlin (2006), "Threshold Effects in the Public Capital Productivity: An International Panel Smooth Transition Approach”, Document de Recherche du Laboratoire d'Economie d'Orléans.

Fratzscher, M. (2012), "Capital Flows, Push versus Pull Factors and the Global Financial Crisis", Journal of International Economics, 88, pp. 341-356.

Fratzscher, M., M. L. Duca, and R. Straub (2013), "On the International Spillovers of US Quantitative Easing", ECB Working Paper Series, No. 1557.

Fouquau J., C. Hurlin, and I. Rabaud (2008), "The Feldstein-Horioka Puzzle: A Panel Smooth Transition Regression Approach", Economic Modelling, 25(2), pp. 284-299.

Furceri, D., S. Guichard, and E. Rusticelli (2011), "Episodes of Large Capital Inflows and the Likelihood of Banking and Currency Crises and Sudden Stops", OECD Economics Department Working Papers, No. 865.

Gauvin L., C. McLoughlin, and D. Reinhardt (2013), "Policy Uncertainty Spillovers to Emerging Markets - Evidence from Capital Flows", Banque de France Working Papers, No. 435.

González A., T. Teräsvirta, and D. van Dijk (2005), "Panel Smooth Transition Regression Models", SSE/EFI Working Paper Series in Economics and Finance, No. 604.

Hansen, B. E. (1996), "Inference When A Nuisance Parameter Is Not Identified Under the Null Hypothesis", Econometrica, 64, pp. 413-430. 
Hansen B. E. (1999), "Threshold Effects in Non-dynamic Panels: Estimation, Testing, and Inference", Journal of Econometrics, 93, pp. 334-368.

IMF (2013a), "The Interaction of Monetary and Macroprudential Policies".

IMF (2013b), "Guidance Note for the Liberalization and Management of Capital Flows".

IMF (2013c), "Global Impact and Challenges of Unconventional Monetary Policies - Background Paper”.

Moore, J., S. Nam, M. Suh, and A. Tepper (2013), "Estimating the Impacts of U.S. LSAPs on Emerging Market Economies' Local Currency Bond Markets”, Federal Reserve Bank of New York Staff Report No. 595.

Yoon, K. and J. H. Kim (2012), "Effects of Global Liquidity on Capital Flows to EMEs, and Their Policy Implications" (in Korean), Bank of Korea Discussion Paper Series, No. 2012-7. 


\section{Appendix}

Figure A.1: Three Threshold Variables' Time Profiles

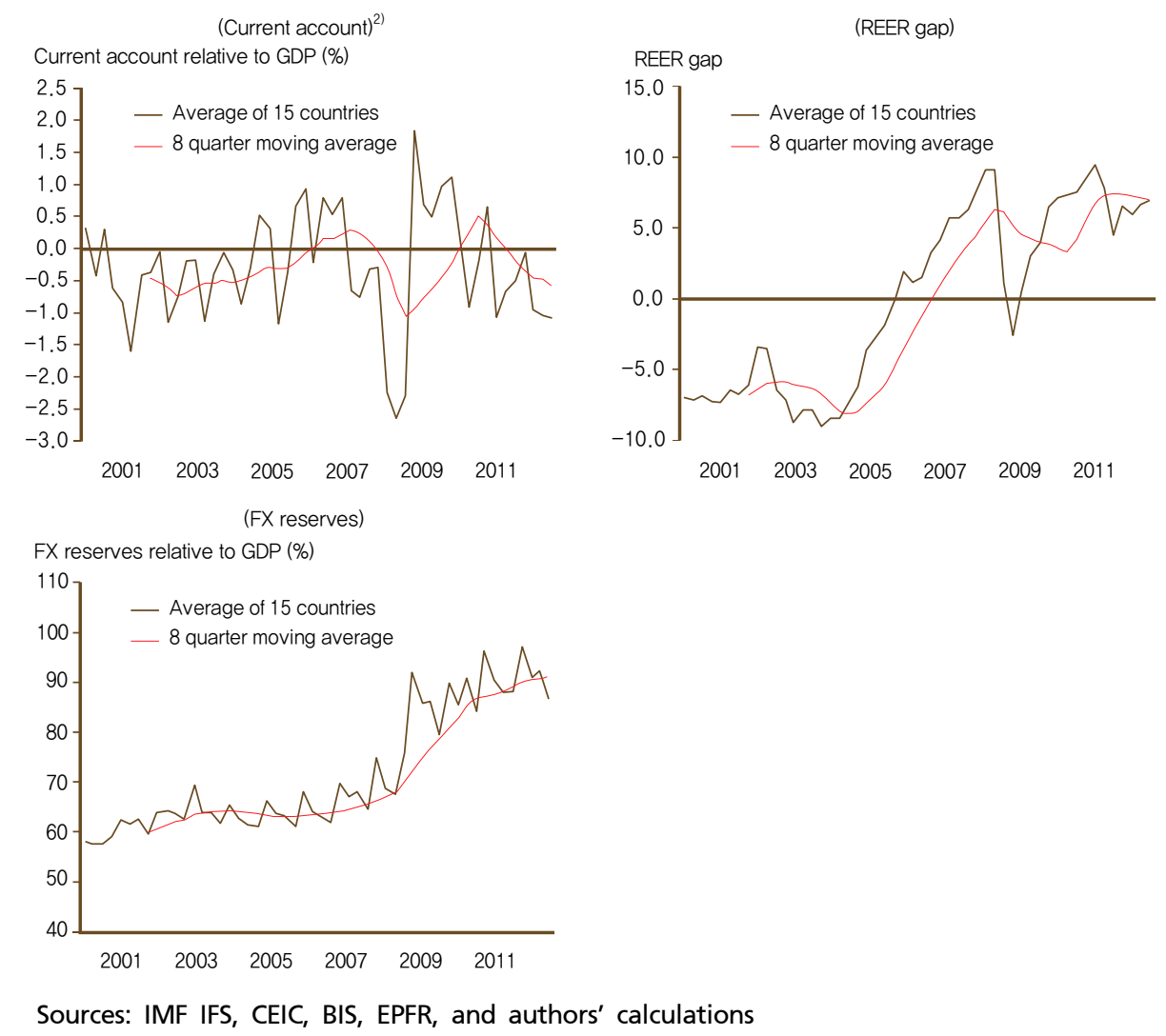




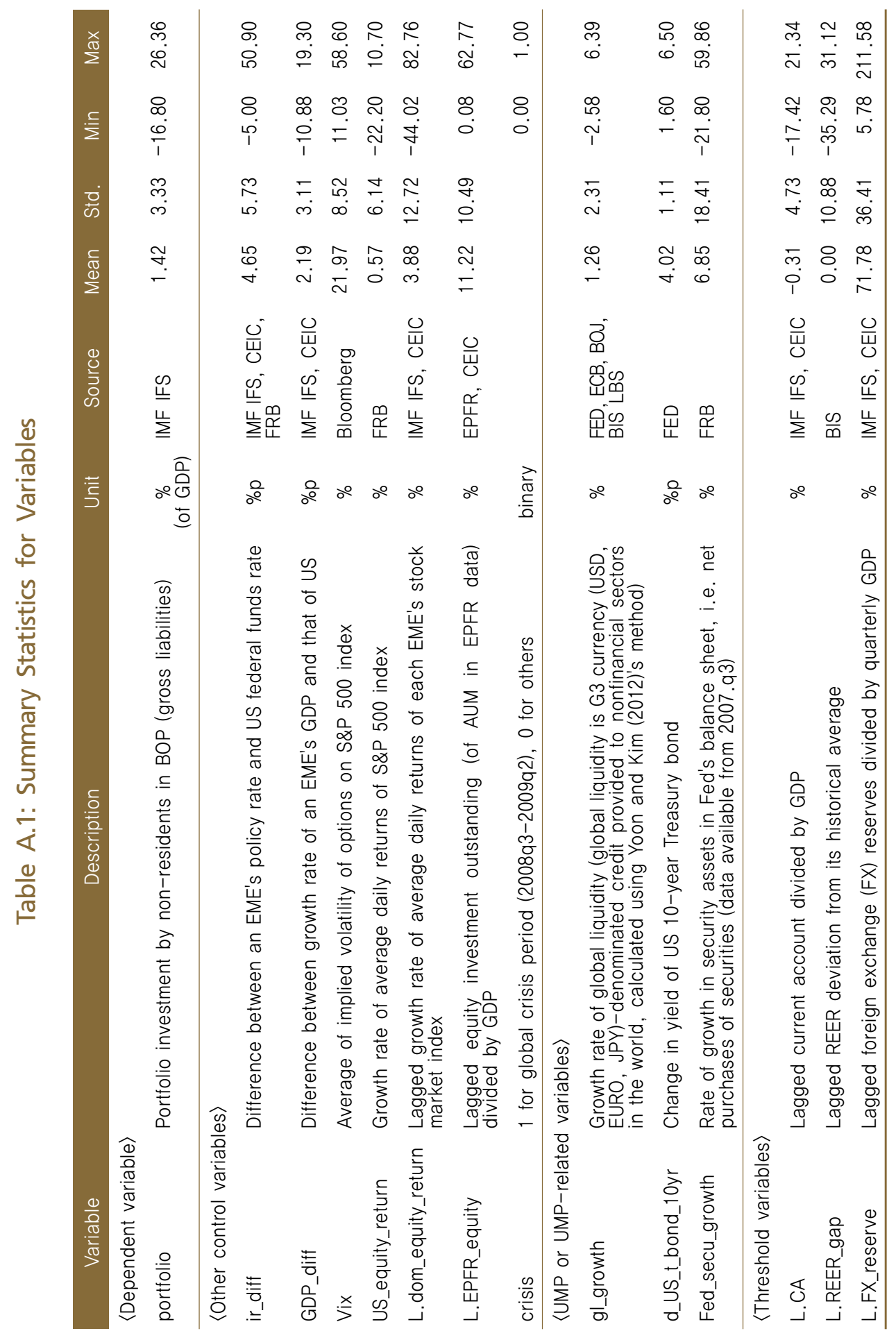




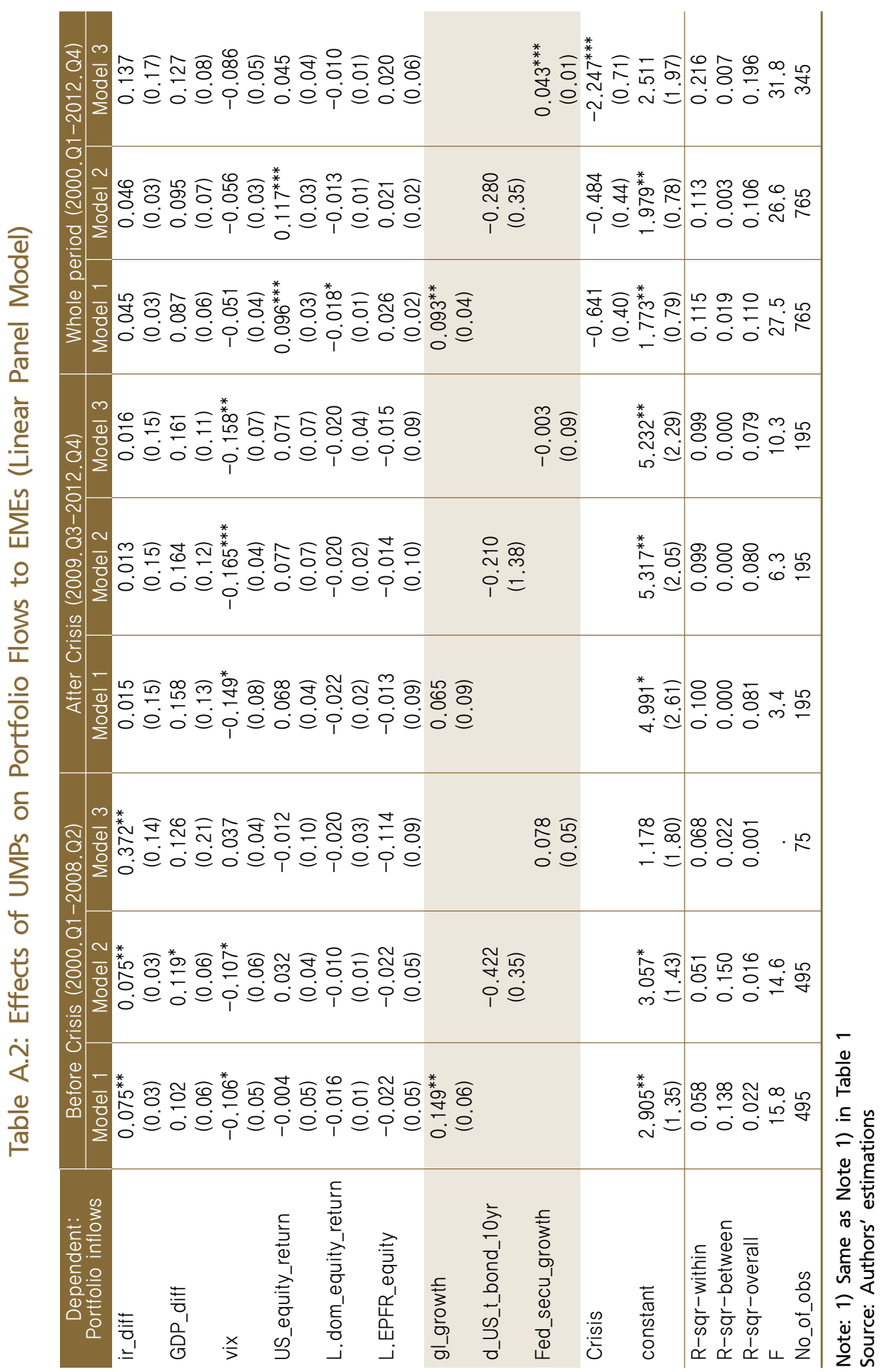




\section{<Abstract in Korean>}

\section{윤경수*, Christophe Hurlin**}

본 논문은 선진국의 비전통적 통화정책(UMPs)이 신흥국에 대한 국제 포트폴리오투자에 미치는 영향이 국가별로 그리고 시기별로 다르게 나타나는지 여부를 PSTR (panel smooth transition regression) 모형을 통해 분석하였다. 분석결과 UMPs의 국제 포트폴리오투자에 대한 영향이 국가별 그리고 시기별로 다른 비선형성을 확인하였으며, 각국의 경상수지, 환율, 외환보유액 등이 동 이질성을 유발시키는 것으로 나타났다. 양호한 경상수지, 역사적 평균보다 저평가된 실질실효환율, 많은 외환보유액은 UMPs를 양적으로 직접 측정한 지표인 미 연준의 자산매입이 증가하는 경우 더 많은 포트폴리오 투자자금 유입을 초래하였던 반면, UMPs를 가격지표로 직접 측정한 미 국채 10 년 수익률이 하락한 경우에는 오히려 더 적은 자금유입을 초래하는 것으로 분석되었다. 따라서 양적완화 축소 등 선진국 비전통적 통화정책의 방향전환시 금융시장 불안으로 가격변수가 초기에 민감하게 반응하는 경우 대외 기초여건이 취약한 국가가 상대적으로 더욱 부정적인 영향을 많이 받게 될 것이나, 선진국 및 세계경제의 경기회복이 보다 뚜렷해지면 민간부문의 신용창출로 글로벌유동성이 증가하면서 정책방향 전환의 부정적 영향이 완화될 것으로 전망된다.

* 한국은행 국제국 국제연구팀 차장

** 프랑스 올레앙대학(University of Orléan) 경제학과 교수 